\title{
Transitions in sandflat biota since the 1930s: effects of sea-level rise, eutrophication and biological globalization in the tidal bay Königshafen, northern Wadden Sea
}

\author{
Juliane Schumacher • Tobias Dolch • \\ Karsten Reise
}

Received: 20 November 2013/Revised: 27 February 2014/ Accepted: 10 March 2014/Published online: 26 March 2014 (c) Springer-Verlag Berlin Heidelberg and AWI 2014

\begin{abstract}
Conspicuous macrozoobenthos and vegetation of intertidal sandflats in Königshafen (Island of Sylt, SE North Sea) were mapped in 1932, 1988 and 2008. Higher water levels since the 1930s with a concomitant increase in tidal dynamics are assumed to have weakened sediment stability. This dissolved the distinctly banded macrobenthic zonation of the 1930s. Near high water level, cyanobacterial mats with associated beetles, belts of the mudshrimp Corophium volutator and the seagrass Zostera noltii have vanished, while the range of the lugworm Arenicola marina has extended towards the shore. Near low water level, sandy elevations have become permanently submerged because a tidal creek has widened its bed. In 1988, extensive green algal mats and the almost complete absence of seagrass are attributed to peak eutrophication. This partially reversed until 2008. The mussel Mytilus edulis had strongly extended its beds along the creek in 1988. These were taken over by introduced Pacific oysters Crassostrea gigas in 2008. Also in 2008, the cordgrass Spartina anglica, another introduced species, grew into large tussocks where cyanobacterial mats and a Corophium-belt had been mapped in the 1930s. Former benthic patterns may have little chance of resurrection by conventional nature protection because these small-scale shifts represent responses to regional and global change.
\end{abstract}

Keywords De-eutrophication · Intertidal · Introduced species $\cdot$ Long-term changes $\cdot$ Macrobenthos $\cdot$ Sea-level rise . Wadden Sea

Communicated by H.-D. Franke.

J. Schumacher · T. Dolch $(\bowtie) \cdot$ K. Reise

Alfred Wegener Institute Helmholtz Centre for Polar and Marine

Research, Wadden Sea Station Sylt, 25992 List, Germany

e-mail: Tobias.Dolch@awi.de

\section{Introduction}

Long-term ecological research is essential to understand the composition and functioning of present coastal ecosystems (Müller et al. 2010). During the twentieth century, ecological conditions of coasts all over the world have undergone drastic changes (Valiela 2005; Lotze et al. 2006). In north-western Europe, coastal marine benthos has changed considerably (Rasmussen 1973; Pearson et al. 1985; Rosenberg et al. 1987; Kröncke 2011), including the Wadden Sea (Beukema and Dekker 2005, 2011; Jensen 1992; Kraan et al. 2011; Reise et al. 1989, 2008; Schückel and Kröncke 2013; Weijerman et al. 2005). Most changes in the Wadden Sea have been attributed to eutrophication (e.g. van Beusekom 2005), to the loss of apex predators (Lotze 2005), fisheries (Piersma et al. 2001), artificial shores (Reise 2005), alien invaders (Buschbaum et al. 2012) and to climate change (Beukema and Dekker 2005; Diederich et al. 2005; Loebl et al. 2006; Nehls et al. 2006, Witte et al. 2010). Here, we add a long-term study on sandflat benthos to further unravel small-scale responses to large-scale causes in a coastal ecosystem.

A sheltered bay named Königshafen at the northern tip of the island of Sylt in the south-eastern coastal North Sea provides an excellent opportunity for long-term comparisons of marine benthos. In the 1930s, Wohlenberg (1937) investigated habitat characteristics and macrobenthos of the intertidal Königshafen and mapped benthos at selected mudflats and sandflats (Fig. 1). One of these mudflats was revisited by Reise et al. (2008) and considerable changes were revealed. Two sandflats were also revisited in 1988 (Reise et al. 1989). Together with a third sandy site, these three sandflats are the subjects of this study which was performed in August 2008. Previously, it was concluded that changes were mainly due to eutrophication triggering 

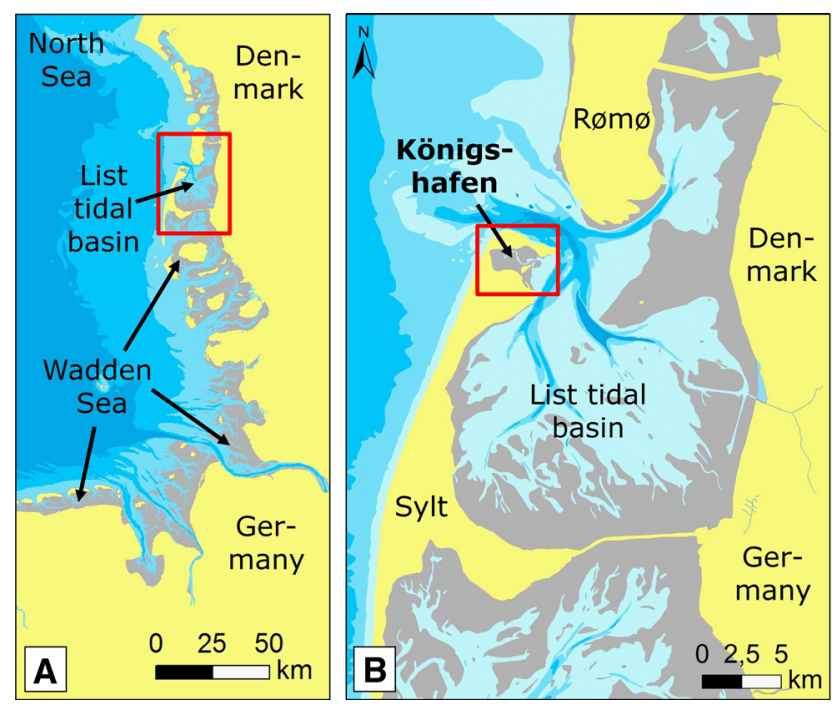

Fig. 1 Königshafen (subimage C; Wohlenberg 1937: Abb. 1), an intertidal bay at the island of Sylt (subimage B) in the northern Wadden Sea (subimage A), dunes in black, salt marsh stippled, low tide line dotted, bars mark intertidal transects. Rectangles in red show

massive green algal mats, an expansion of mussel beds and an increased abundance of polychaete worms (Reise et al. 1989).

However, Reise and van Beusekom (2008) suggested that a new direction of change has commenced because nutrient loads into the Wadden Sea have decreased in the last two decades, while temperature, high tide level and the share of alien species have increased. We here hypothesize (1) that increased hydrodynamics affect the benthos of sandy flats even stronger than the benthos of muddy flats due to higher exposure, (2) that recent de-eutrophication has already visible effects and (3) that introduced nonnatives have become a major cause of benthic change.

\section{Materials and methods}

Study area

Königshafen is a sheltered bay with an extent of $3.5 \mathrm{~km}$ $(\mathrm{E}-\mathrm{W})$ by $1.4 \mathrm{~km}(\mathrm{~N}-\mathrm{S})$ at the northern end of the island of Sylt in the northern Wadden Sea (SE coastal North Sea). The bay is part of the List tidal basin which is formed by the German island of Sylt, the Danish island of Rømø, the mainland and causeways which connect the latter with the islands. Present tidal range is $1.8 \mathrm{~m}$, salinity approximately 30 psu and mean annual water temperature in the last century was $9{ }^{\circ} \mathrm{C}$ (Reise et al. 1994). In the nearby village of List, south of the bay, the Wadden Sea Station was founded in 1924. Several scientists have studied the ecology and geology of Königshafen since then (see Reise et al.

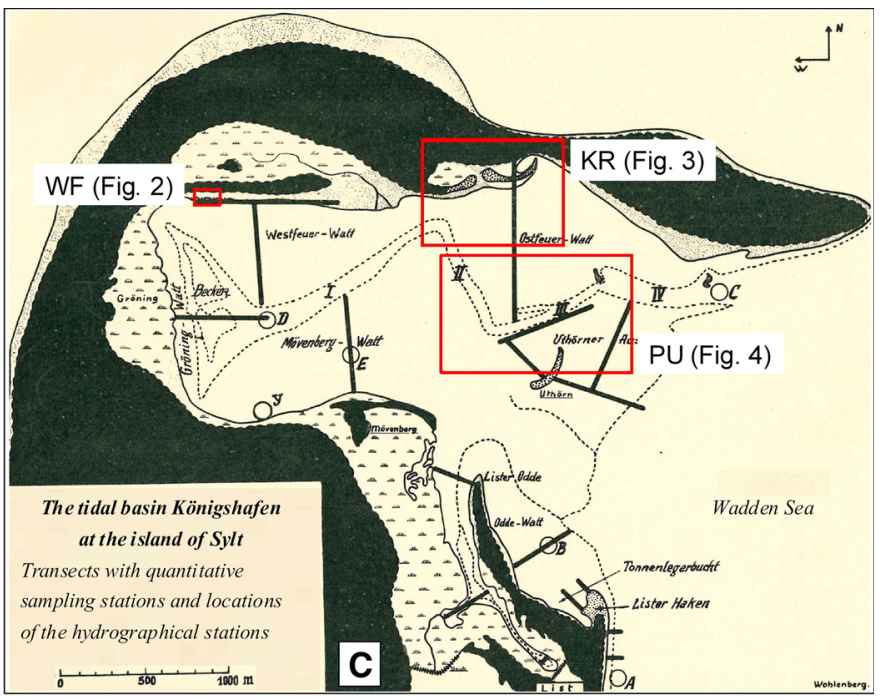

the position of the studied sites: sandy shore at Westfeuer-Watt (WF), sandy shore at Kersten Rimling (KR), sandy shoals around the main tidal gully near Uthörn (PU). The transects shown in Wohlenberg's map are not relevant for this study (color figure online)

2008). Wohlenberg (1937) mapped and described the macrobenthos of Königshafen in relation to habitat characteristics in 1932 and 1934. His maps and descriptions provided the basis for long-term comparisons of tidal flat sediment types (Austen 1994; Dolch and Hass 2008) and macrobenthos (Reise 1985; Reise et al. 1989, 2008). In August 2008, we reinvestigated three areas mapped by Wohlenberg in 1932 (Fig. 1): an area of approximately $70 \times 140 \mathrm{~m}$ at the sandy beach of Westfeuer-Watt (WF) (Wohlenberg 1937: Fig. 53), a lagoonal shore at Kersten Rimling (KR) of approximately $400 \times 800 \mathrm{~m}$ (Wohlenberg 1937: Fig. 21 and 23), and sandy elevations alongside the main tidal channel of Königshafen near Uthörn peninsula (PU) with an area of approximately $700 \times 1,100 \mathrm{~m}$ (Wohlenberg 1937: Fig. 58). The latter two were already reinvestigated in 1988 (Reise et al. 1989).

Benthos data

A comparison with Wohlenberg's data from the 1930s has to struggle with three main problems:

1. The exact positions and the scale of the maps drawn by Wohlenberg are not given. Only his Fig. 1 (shown in Fig. 1) is scaled and the locations have to be inferred from that coarse-scaled map. We used historic and current aerial photographs (see Dolch et al. 2013: Fig. 2; Dolch and Reise 2010: Fig. 3) to infer locations.

2. The maps drawn by Wohlenberg are semi-schematic and do not show all organisms encountered. This is obvious when compared to his list of species in Chapter II (Wohlenberg 1937: 24-26). Apparently, he 
opted for the most conspicuous and what he regarded as the most characteristic taxa and habitat structures. Evidently, he also was fond of beetles. However, we tried to design our survey in the same way to make the results as comparable as possible.

3. Wohlenberg did not explicitly describe his methods of assessment. He visited Königshafen in summer of 1932 and again in the summers of 1934 and 1936. Apparently, he took samples of $500 \mathrm{~cm}^{2}$ to a depth of $30 \mathrm{~cm}$ and washed the sediment through sieves of which the finest mesh size was $1 \mathrm{~mm}$. It also seems that he used smaller sample areas where densities of small benthos were high (Wohlenberg 1937: 23). His samples were schematically characterized by surface forms, vegetation, sediment colour, conspicuous strata and water content. He occasionally provided quantitative data but gave more weight to qualitative analysis. We did likewise for the sake of comparison.

The problems mentioned above necessitate a cautious attitude to avoid confusing the methodological with the real differences between the 1930s and today. A statistical treatment of the early data sets is not possible. Nevertheless, his detailed verbal descriptions form a reliable basis for the interpretation of his surveys.

To create maps comparable with those of Wohlenberg, we used aerial photographs from 1936, 1984 and 2008, Global Positioning System (GPS) and the Geographic Information System (GIS) 'ArcGIS 10.0', and grids with qualitative observation points. At study site WF, grid units were $10 \times 10 \mathrm{~m}$, while they were $30 \times 60 \mathrm{~m}$ at $\mathrm{KR}$ and $50 \times 50 \mathrm{~m}$ at PU. At each point, a plot was chosen randomly by throwing a $30 \times 30 \mathrm{~cm}$ frame. Within such plots, the presence of all taxa visible on the sediment surface was recorded, including characteristic faecal mounds or protruding tubes. Subsequently, the sediment below such a plot was excavated with a fork to a depth of $30 \mathrm{~cm}$ and all fauna visible was recorded (see "Appendix"). When necessary, species were identified with the help of a stereomicroscope in the laboratory. In total, 257 plots were sampled, 63 at study site WF, 101 at site KR and 93 at site PU.

The position and size of mussel beds and tussocks of Spartina anglica were recorded in the field using GPS. In the same way, the areas were recorded where patches of dwarf seagrass Zostera noltii covered at least 60 percentage of the surface, estimated during low tide exposure when blades were lying on the sediment.

\section{Review of physical change}

Physical changes were not measured in this study but are summarized here from the literature, and geomorphologic aspects are taken from aerial photographs in Dolch (2008). The shape of Königshafen has changed little over the past century except for the embankment of a salt marsh area in the south in 1937 and a peninsula created by nourished sand 70 years ago (Kolumbe 1932; Newig 1980; Bayerl and Hilgelke 1994). Although most of the shores show signs of retreat by erosion, the rate is rather small.

Sediments in Königshafen have two sources of origin: coarse-grained sand has been supplied by large mobile dunes which originated at the exposed western shore of the island and migrated over the island into the tidal area, while fine-grained sediments were deposited by tidal waters (Wohlenberg 1937; Priesmeier 1970). The intertidal flats of Königshafen are mainly sandy with interspersed muddy areas. The latter have decreased considerably over time (Austen 1994; Dolch and Hass 2008). Rising water levels and increasing tidal range have presumably caused stronger currents which selectively removed fine-grained sediments, while the coarse-grained sand have remained, resulting in the observed increase of sandiness. Relative mean sea level increased at the nearest tide gauge (List harbour) by $2 \mathrm{~mm} \mathrm{a}^{-1}$ between 1937 and 2008 (Wahl et al. 2011). Mean tidal range increased by $3.5 \mathrm{~mm} \mathrm{a}^{-1}$ between 1957 and 1987 (Jensen et al. 1992), and the winter storm surge height increased by about $3 \mathrm{~mm} \mathrm{a}^{-1}$ between 1958 and 2002 (Weisse and Plüß 2006).

\section{Results}

All three sandy sites mapped for macrobenthos in the 1930s have undergone considerable change in habitat morphology, species composition and distribution.

Sandy shore at Westfeuer-Watt (WF) (for location see Fig. 1)

This sandy shore habitat has changed conspicuously since 1932 (Fig. 2). While dune cliff and beach have remained approximately in the same position, sandy hooks extending from the beach have vanished. Interspersed areas of sand consolidated by cyanobacterial mats and populated by the staphylinid beetle Bledius spectabilis as mapped by Wohlenberg (1937: Fig. 53) are gone as well (Fig. 2). The zonation of distinct belts of macrobiota parallel to the shore as observed in the 1930s has been replaced by bedforms perpendicular to the shore in 2008. This pattern is disrupted by a cluster of tussocks of the invasive cordgrass $S$. anglica. A small tussock was first encountered in the late 1980s (pers. obs.). In 2008, three large tussocks occurred with diameters of 10, 15 and $16 \mathrm{~m}$ and a couple of smaller ones (diameters 1-5 m). Between the large tussocks, a sand bar has developed. 


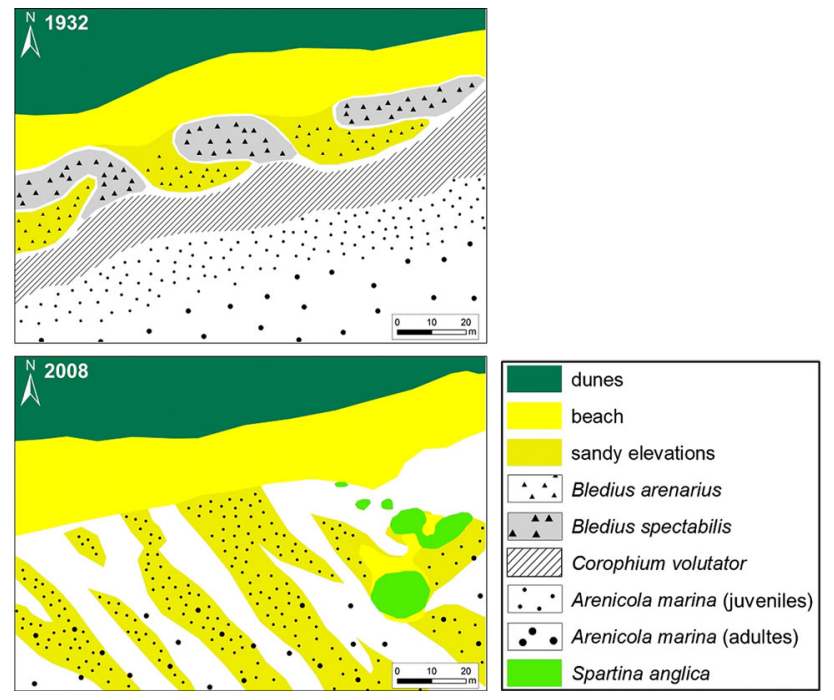

Fig. 2 Habitats and conspicuous macrobenthos at Westfeuer-Watt (WF) in 1932 and 2008

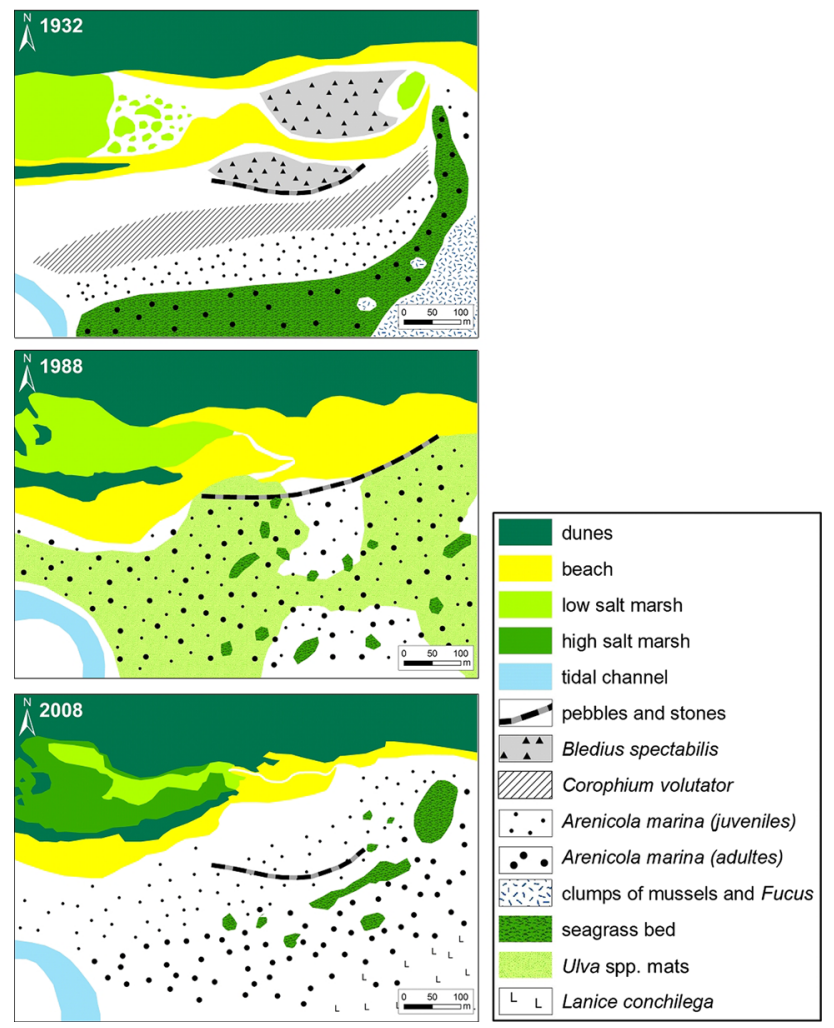

Fig. 3 Habitats and conspicuous macrobenthos at Kersten Rimling (KR) in 1932, 1988, and 2008

The sandy hooks that were 10-20 m long and composed of coarse sand, which was indicated by Wohlenberg (1937), may be precursors of the much longer sandy elevations transversal to the shore observed in 2008 which are distinctly visible on recent aerial photographs. According to Wohlenberg (1937), the short hooks were densely populated by Bledius arenarius and its carabid predator Dyschirius angustatus, while the interspersed lower flats were covered with mats of cyanobacteria and were inhabited by $B$. spectabilis and the carabid beetle Heterocerus flexuosus. In 2008, B. arenarius and B. spectabilis were not found at this site but are still present in other parts of Königshafen albeit in small numbers.

In downslope direction towards low tide level, a second belt was occupied by the amphipod Corophium volutator in 1932 but absent in 2008. A third belt with juvenile and adult lugworms Arenicola marina (Wohlenberg 1937, Abb. 53; Fig. 2) had extended landward in 2008. The juvenile lugworms mainly occurred on the transverse sandy elevations while the adults were found in the lower part of the shore. C. volutator was entirely absent as were the mats of cyanobacteria.

Sandy shore at Kersten Rimling (KR) (for location see Fig. 1)

This sandy shore habitat has also changed conspicuously since 1932 (Fig. 3). A lagoon partly sheltered by a sandy spit ('Rimling' in local language) gradually had vanished. In the 1980s, the spit had already fused with the shore. In the western part of the lagoon, the low salt marsh with Salicornia herbacea (now: S. europaea.s.1.) and Suaeda maritima (Wohlenberg 1937: Figs. 21, 23) grew to an upper salt marsh, and the eastern part was bare sand (Reise et al. 1989: Fig. 4). Until 2008, the vegetated spit grew longer and the sandy beach area became smaller than in the 1980s. The inner part of the former lagoon further grew upwards. An upper salt marsh with Armeria maritima, Festuca rubra and Halimione portulacoides was found in the inner part of the lagoon, while the lower salt marsh persisted only along a narrow channel. The vegetation was short-grazed by sheep.

Seaward of the sandy spit and in the eastern part of the lagoon, Wohlenberg recorded mats of cyanobacteria and a dense population of the roof beetle $B$. spectabilis, followed by a belt of $C$. volutator in the 1930s. Both the Bledius- and the Corophium-zone were absent in 1988 and 2008. Only a few burrows of $B$. arenarius were found on the beach. Further, down the slope towards low tide level, Wohlenberg mapped A. marina, followed by a belt of seagrass $Z$. noltii. This biotic zonation had dissolved in the 1980s. Instead, mats of opportunistic green algae covered a large part of the sediment surface (Reise et al. 1989: Fig. 4). Wohlenberg did not mention any mats of green algae in the 1930s. In 2008, the mats were gone, but a few strings of green algae were found, mainly filiform Ulva spp. and Chaetomorpha spp. A single plant of S. anglica was detected near the shore in August 2008.

The range of A. marina has extended since the 1930s. In 1988 and 2008, it was found on the entire sandflat in high 


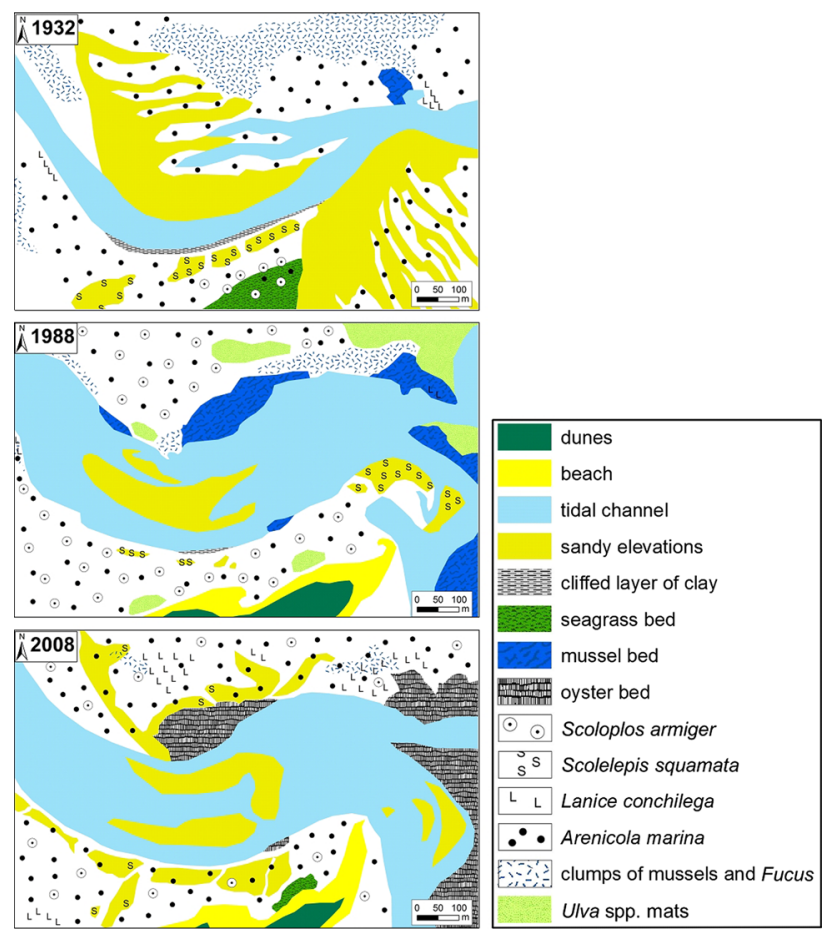

Fig. 4 Habitats and conspicuous macrobenthos on sandy elevations around the tidal creek near Uthörn (PU) in 1932, 1988 and 2008

numbers. According to Wohlenberg's map, juveniles and adults of A. marina settled in separate belts in the 1930s. In 1988, this separation was no longer apparent but reappeared to some extent in 2008.

A slight reversal may have taken place in the seagrass $Z$. noltii in this area. In 1932, a dense belt occurred. In the 1980 s, seagrass was scattered over most of the area but occurred nowhere in dense patches. In 2008, dense patches were found in a kind of belt at approximately the position of $Z$. noltii in the 1930s. In addition, few plants of $Z$. marina were found in 2008.

In the lowest part of the sandflat, Wohlenberg found clumps of the blue mussel Mytilus edulis with the attached brown algae Fucus vesiculosus. In 1988, such clumps were not recorded, and in 2008, only a few were found in the area. However, where Wohlenberg mapped M. edulis, we observed the tube worm Lanice conchilega in high numbers in 2008 (Fig. 3).

Sandy elevations around the tidal channel near Uthörn (PU) (for location see Fig. 1)

A considerable habitat and macrobenthic change has taken place also near low tide level around the main tidal creek of Königshafen (Fig. 4). The bed of the channel has widened significantly since the 1930s. A large part of the tidal flat mapped by Wohlenberg was permanently submerged in 1988 (Reise et al. 1989: Fig. 5) and also in
2008. South of the tidal channel a peninsula was artificially created by sand nourishment in the 1940s, extending into the survey area in 1988 and 2008. A conspicuous layer of clay was photographed by Wohlenberg and mapped along the southern bank of the creek (Wohlenberg 1937: Figs. 58, 65). In the 1980s, only a small part was still visible and in August 2008, this layer of clay was not exposed during low tide but could be found at $0.3-0.5 \mathrm{~m}$ below mean low water level. Along the tidal channel, Wohlenberg mapped sand bars (he wrote of areas with 'clean' sand) populated by the polychaetes Scolelepis squamata and Ophelia rathkei together with a tiny roof beetle Diglotta mersa which dwells in air bubbles within loose sand (Wohlenberg 1937: Figs. 58, 61, 62). In 1988, these sand bars were much smaller, while in 2008, they had grown again to some extent (Fig. 4). S. squamata was found in most of them and also a few individuals of $D$. mersa. On the sandy tidal flats, the lugworm A. marina was widespread at all times, mainly adults. Scoloplos armiger may have become more common than in the 1930s. The area with the tubeworm L. conchilega had increased. In the 1930s and 1980s, it was found at two small plots along the tidal channel, while in 2008, there were three large patches where L. conchilega occurred.

Wohlenberg mapped large areas with clumps of $M$. edulis to which the brown algae $F$. vesiculosus was attached. However, in the 1930s, only a single distinct mussel bed occurred at the knee of the tidal channel overgrown by fucoid algae and Semibalanus balanoides $\mathrm{L}$. (Wohlenberg 1937: Fig. 59). In the 1980s, mussel beds occurred all along the northern banks of the tidal channel, and some showed scars from commercial dredging for mussels (Reise et al. 1989: Fig. 5).

In 2008, beds of $M$. edulis had been invaded by the Pacific oyster Crassostrea gigas. These were introduced a few kilometres south of Königshafen for aquaculture , were recorded for the first time on a mussel bed in Königshafen in 1991 (Reise 1998), and have increased rapidly in density since 2002. It took over on all mussel beds, although mussels still occur hidden among the larger oysters (Fig. 4).

Green algal mats were absent in the 1930s, common in the 1980s (Reise et al. 1989), and in 2008, no mats were found anymore apart from small bunches scattered across the tidal flats. A bed of Z. noltii, growing in an area south of the tidal channel in the 1930s, became covered by the artificial sand nourishment. However, in 2008, a small bed re-emerged near the beach of the nourished area.

\section{Discussion}

Three sandy sites mapped in 1932 were reinvestigated in 2008, and two of these also in 1988 . We confined data 
presentation to conspicuous benthic species to avoid confusion caused by methodological uncertainties. It may be presumptuous to infer general patterns of change from no more than three localities and five snapshot surveys. However, the third author visited the sites continuously since the 1970s, and the presented maps show consistent changes which allow us to hypothesize three prevalent processes changing the benthos of the sandy intertidal since the 1930s: (1) an increasing tidal range and high water level entailed hydro- and sediment dynamics which in turn caused the loss of benthos associated with calmer and more stable conditions; (2) in the 1980s, eutrophication effects became apparent but declined again until 2008; and (3) while two introduced, non-native ecosystem engineers have presumably caused permanent change. These inferences are compared to results of other long-term studies on intertidal flats in the Wadden Sea to explore consistency in this ecosystem.

\section{Sea-level rise}

One cannot expect distribution and composition of macrobenthos to remain the same when the physical regime has changed. In Königshafen, water levels have increased since the 1930s. According to the local tide gauge, relative sea level has risen by $14 \mathrm{~cm}$ since then (Wahl et al. 2011), and mean high tide level has increased by approximately $20 \mathrm{~cm}$ and tidal range by $30 \mathrm{~cm}$ (Jensen et al. 1992; Weisse and Plüß 2006). There is concern that an acceleration of global sea-level rise associated with climate warming is already underway (i.e. Vermeer and Rahmstorf 2009; Kemp et al. 2011). However, there are also various regional and local factors such as embankment or reduction of tidal catchment area which may contribute to higher water levels in our study area (Weisse and Plüß 2006; Wahl et al. 2011).

Also since the 1930s, an advancing sandiness has been noted for Königshafen (Austen 1994; Dolch and Hass 2008). This and higher water levels imply that hydrodynamics in the bay have become stronger and sediment less stable than eight decades ago. Morphological changes at the three study sites and a mudflat (see Reise et al. 2008) support this conclusion. The loss of sandy hooks at Westfeuer-Watt (WF, Figs. 1, 2) and the retreat of a sandy spit at Kersten Rimling (KR, Figs. 1, 3) point to erosion at the shore. At the third site (PU), the considerable widening of the channel bed indicates even stronger erosion at low tide level and below. At the two nearshore sites, loss of mud and decreasing sediment stability and increasing sandiness are indicated by three biotic changes: (1) the loss of cyanobacterial mats, (2) the loss of dense belts of the mudshrimp $C$. volutator, an amphipod known to dwell in muddy sediments of the upper shore where the lugworm $A$. marina is scarce (Flach 1996), and (3) the concomitant spread of $A$. marina, known to avoid muddy sediments (Reise et al. 2001).

The appearance of large sandy bedforms perpendicular to the shore at Westfeuer-Watt likewise points to increased sediment mobility (Dolch and Reise 2010). A long-term loss of $C$. volutator also occurred elsewhere in Königshafen (Reise et al. 2008) and in other parts of the Wadden Sea. In Jade bay of the southern Wadden Sea, a benthic comparison to the 1930s also revealed a decreasing population of C. volutator (Schückel and Kröncke 2013). This is a sheltered bay with extensive muddy flats where an increasing sandiness has not been observed. Thus, there may be other, more regional causes for the decline of $C$. volutator, and more research is needed on this issue. However, for Königshafen, we suggest that increased hydrodynamics have been the ultimate cause of change in the nearshore benthic zone. This conclusion is supported by Puls et al. (2012) showing large-scale benthic patterns on tidal flats to be best predicted by hydrodynamics. The effects of sea-level rise on the sedimentary system of the Wadden Sea are still under discussion (van Goor et al. 2003; CPSL 2005; Wang et al. 2012). Tidal basins are expected to respond individually, depending on size, tidal volume and shape. The larger the tidal basin and tidal inlet, the lower may be the ability to retain sediments. The negative sediment budget of the large List tidal basin-to which Königshafen belongs-has already been pointed out in Gätje and Reise (1998). In smaller tidal basins, sedimentation still tends to compensate sea-level rise.

\section{Eutrophication}

In the Wadden Sea, eutrophication has been shown to have aggravated since the second half of the previous century, culminating in the 1980s and easing off since the 1990s (van Beusekom 2005). Some of the benthic changes we observed may reflect this development: (1) absence of green algal mats in the 1930s, their extensive occurrence triggered by a high nutrient supply in the 1980s, and only few green algal strings in the 2000s. At a nearby mudflat, green algal mats were still common but variable throughout the latter period (Reise et al. 2008). In the Wadden Sea, green algal mats attained a maximum in the early 1990s (Kolbe et al. 1995; Reise and Siebert 1994) and have varied in extent with nitrogen load in the riverine runoff since then (van Beusekom et al. 2009). (2) A distinct belt of intertidal seagrass, which is sensitive to eutrophication, was present in the 1930s, almost absent in 1988, and present in patches of $Z$. noltii in 2008. Dolch et al. (2013) reconstructed the extent of intertidal seagrass beds in the entire Northfrisian Wadden Sea including Königshafen bay since the 1930s and found a decline until the 1990s when an ongoing recovery commenced. The intermittent losses are assumed 
to be mainly caused by adverse effects of sediment mobility and by eutrophication (Dolch and Reise 2010; Reise and Kohlus 2008). A similar long-term trend was observed in Jade Bay where eutrophication is regarded to be primarily responsible for this development as sediment dynamics have not been evoked to have had an effect (Schückel and Kröncke 2013). (3) A more uncertain link to eutrophication may be the increase in mussel bed area from 1932 to 1988 along the tidal creek in Königshafen. This was suggested by Reise et al. (1989) and for Ho Bay, about $50 \mathrm{~km}$ north of Königshafen, by Jensen (1992), assuming an effect of increased phytoplankton food. An increase of mussel bed area from the 1930s to the 1970s and a subsequent decrease has been recorded for Jade bay in the southern Wadden Sea (Schückel and Kröncke 2013). While the increase might have been an effect of eutrophication, the decrease here and in the western Dutch Wadden Sea has been attributed to the mussel fishery (Herlyn and Millat 2000; Kraan et al. 2011). Nehls et al. (2006) attribute a recent decrease in mussel bed area around the island of Sylt to recruitment failure, most likely caused by predation on mussel spat, probably facilitated by a series of mild winters (Beukema and Dekker 2005). Processes like these may have also affected mussel bed area in previous times, and eutrophication may not have been the only major factor.

\section{Introduced non-natives}

The advancing tide of introduced alien species in the Wadden Sea has been reviewed by Buschbaum et al. (2012). At our study sites, two conspicuous invaders have altered the benthic pattern since the 1930s: (1) tussocks of the cordgrass $S$. anglica became established on the sandflat at Westfeuer-Watt (Fig. 2). This was already recorded by Loebl et al. (2006) who propose that increasing summer temperature since the 1990s has facilitated the spread of $S$. anglica. We also found a single pioneer plant at Kersten Rimling (Fig. 3) which point to a further spread in Königshafen. (2) In 2008, all mussel beds along the tidal creek of Königshafen were overgrown by the Pacific oyster C. gigas. At closer look, mussels remained abundant among the larger oysters, but the latter provided the main benthic structure. The area covered by mussel beds in 1988 and oyster beds in 2008 was similar. C. gigas became dominant on mussel beds in the List tidal basin since 2002 (Diederich et al. 2005; Büttger et al. 2011). The spread of C. gigas is assumed to have been facilitated by the mussels themselves as they provided a hard substrate suitable for oysters to grow at. Higher summer temperature, which promote oyster recruitment, is recorded since the 1990s, and a massive decline observed after winters with destructive ice shear (2009/2010 and 2010/2011) indicates the importance of climatic change.
The introduced $S$. anglica and $C$. gigas function as ecosystem engineers (Bouma et al. 2009; Tang and Kristensen 2010; Kochmann et al. 2008; Markert et al. 2010) and affect the entire benthic assemblage structure. For both species, there is no evidence that these non-natives may lose again their prominent role near high and near low water level, respectively. S. anglica is occupying a niche that was not occupied before by any native species in Königshafen. C. gigas seems to occur beside mussels that dominated the same locations before. Both introduced species may provide habitat structures for further nonnatives. Other studies on long-term change in the benthos of the Wadden Sea have shown that alien species significantly increased species richness in this ecosystem (Beukema and Dekker 2011; Schückel and Kröncke 2013).

\section{Conclusions}

Comparing the macrobenthos of sandy tidal flats in Königshafen of the Island of Sylt from the 1930s, 1980s and 2000s, we found that conspicuous species have undergone a strong change over the last decades. The apparent zonation outlined by Wohlenberg (1937) for the sandy nearshore zone disintegrated because major components have become scattered, rare or lost: cyanobacterial mats with staphylinid beetles vanished, a distinct belt of the mudshrimp C. volutator is entirely gone, and a belt of seagrass dissolved into patches. Particularly, the lugworm A. marina has occupied the space where these assemblages had been in the 1930s. This indicates an advancing sandiness at these sites. Tussocks of the introduced cordgrass $S$. anglica, and large sandy elevations further contribute to the change.

Close to low water level, a tidal channel has strongly widened its bed and epibenthic suspension feeders attained a much larger bed size than in 1932. This spread was accomplished by the mussel M. edulis which later became partially displaced by the introduced Pacific oyster $C$. gigas.

As major drivers of these presumably irreversible changes we suggest rising water levels and the biological globalization due to species introductions. Both drivers are likely to proceed. Higher water levels have entailed enhanced hydrodynamics, which in turn caused higher sediment mobility which altered habitats and benthic patterns. As ecosystem engineers, non-native $S$. anglica and $C$. gigas have not only the potential to affect other species already present but may facilitate the establishment of other alien species.

The third driver assumed to have effects on benthic long-term changes is eutrophication. Other than sea-level rise and species introductions, a recent turn to 
de-eutrophication may reverse the effects. However, considering hysteresis and the impossibility to return to natural nutrient levels, eutrophication effects are likely to remain in the Wadden Sea, albeit at a lower level.

Acknowledgments For their significant help and support during field campaigns, we would like to thank Elisabeth -Lilo- Herre and Karolin Thomisch.

\section{Appendix}

See Table 1.

Table 1 Species list (August 2008)

\begin{tabular}{|c|c|}
\hline \multicolumn{2}{|c|}{ Species (found at plots studied) } \\
\hline \multicolumn{2}{|l|}{ Westfeuer-Watt (WF) } \\
\hline Bivalvia & Crustacea \\
\hline Cerastoderma edule & Carcinus maenas \\
\hline Crassostrea gigas $^{\mathrm{a}}$ & Corophium volutator \\
\hline Macoma baltica & Talitrus saltator \\
\hline Mytilus edulis & Crangon crangon \\
\hline Gastropoda & Coleoptera \\
\hline Hydrobia ulvae & Bledius arenarius \\
\hline Littorina littorea & Bledius spectabilis \\
\hline Annelida & Plants \\
\hline Arenicola marina & Spartina anglica ${ }^{\mathrm{a}}$ \\
\hline Heteromastus filiformis & Zostera marina \\
\hline Nephtys hombergii & Ulva spp. \\
\hline \multicolumn{2}{|l|}{ Nereis diversicolor } \\
\hline \multicolumn{2}{|l|}{ Nereis virens ${ }^{\mathrm{a}}$} \\
\hline \multicolumn{2}{|l|}{ Pygospio elegans } \\
\hline \multicolumn{2}{|l|}{ Scoloplos armiger } \\
\hline \multicolumn{2}{|l|}{ Kersten Rimling (KR) } \\
\hline Bivalvia & Crustacea \\
\hline Macoma baltica & Austrominius modestus ${ }^{\mathrm{a}}$ \\
\hline Mytilus edulis & Balanus crenatus \\
\hline Cerastoderma edule & Carcinus maenas \\
\hline \multirow[t]{2}{*}{ Crassostrea gigas $^{\mathrm{a}}$} & Corophium volutator \\
\hline & Crangon crangon \\
\hline Gastropoda & Semibalanus balanoides \\
\hline Littorina littorea & Talitrus saltator \\
\hline \multicolumn{2}{|l|}{ Crepidula fornicata $^{\mathrm{a}}$} \\
\hline \multirow[t]{2}{*}{ Hydrobia ulvae } & Coleoptera \\
\hline & Bledius spectabilis \\
\hline Annelida & Bledius arenarius \\
\hline \multicolumn{2}{|l|}{ Arenicola marina } \\
\hline Lineus virens & Plants \\
\hline Nephtys hombergii & Chaetomorpha linum \\
\hline
\end{tabular}

Table 1 continued

\begin{tabular}{|c|c|}
\hline \multicolumn{2}{|l|}{ Species (found at plots studied) } \\
\hline Nereis diversicolor & Fucus vesiculosus \\
\hline Nereis virens ${ }^{\mathrm{a}}$ & Gracilaria vermiculophylla ${ }^{\mathrm{a}}$ \\
\hline Phyllodoce mисоsa & Spartina anglica ${ }^{\mathrm{a}}$ \\
\hline Eteone longa & Ulva spp. \\
\hline Heteromastus filiformis & Zostera marina \\
\hline Lanice conchilega & Zostera noltii \\
\hline \multicolumn{2}{|l|}{ Polysiphonia elongata } \\
\hline Pygospio elegans & Cyanobacteria \\
\hline \multicolumn{2}{|l|}{ Scolelepis squamata } \\
\hline \multicolumn{2}{|l|}{ Scoloplos armiger } \\
\hline \multicolumn{2}{|l|}{ Tubificidae } \\
\hline \multicolumn{2}{|l|}{ Shoals at Uthörn Priel (PU) } \\
\hline Bivalvia & Plants \\
\hline Cerastoderma edule & Fucus vesiculosus \\
\hline Crassostrea gigas ${ }^{\mathrm{a}}$ & Polysiphonia elongata \\
\hline Macoma baltica & Gracilaria vermiculophylla \\
\hline Mytilus edulis & $\begin{array}{l}\text { Salicornia europaea } \\
\text { Ulva spp. }\end{array}$ \\
\hline Gastropoda & Zostera marina \\
\hline Hydrobia ulvae & Zostera noltii \\
\hline \multicolumn{2}{|l|}{ Littorina littorea } \\
\hline \multicolumn{2}{|l|}{ Crepidula fornicata $^{\mathrm{a}}$} \\
\hline \multicolumn{2}{|l|}{ Annelida } \\
\hline \multicolumn{2}{|l|}{ Arenicola marina } \\
\hline \multicolumn{2}{|l|}{ Eteone longa } \\
\hline \multicolumn{2}{|l|}{ Heteromastus filiformis } \\
\hline \multicolumn{2}{|l|}{ Lanice conchilega } \\
\hline \multicolumn{2}{|l|}{ Lineus virens } \\
\hline \multicolumn{2}{|l|}{ Nephtys hombergii } \\
\hline \multicolumn{2}{|l|}{ Nereis diversicolor } \\
\hline \multicolumn{2}{|l|}{ Nereis virens ${ }^{\mathrm{a}}$} \\
\hline \multicolumn{2}{|l|}{ Phyllodoce mисоsa } \\
\hline \multicolumn{2}{|l|}{ Pygospio elegans } \\
\hline \multicolumn{2}{|l|}{ Scolelepis squamata } \\
\hline \multicolumn{2}{|l|}{ Scoloplos armiger } \\
\hline \multicolumn{2}{|l|}{ Crustacea } \\
\hline \multicolumn{2}{|l|}{ Semibalanus balanoides } \\
\hline \multicolumn{2}{|l|}{ Austrominius modestus } \\
\hline \multicolumn{2}{|l|}{ Balanus crenatus } \\
\hline \multicolumn{2}{|l|}{ Carcinus maenas } \\
\hline \multicolumn{2}{|l|}{ Crangon crangon } \\
\hline Coleoptera & \\
\hline Diglotta mersa & \\
\hline
\end{tabular}

Salt marsh vegetation at $\mathrm{KR}$ is not included

${ }^{\text {a }}$ Non-native or cryptogenic according to Buschbaum et al. (2012) 


\section{References}

Austen I (1994) The surficial sediments of Königshafen—variations over the past 50 years. Helgol wiss Meeresunters 48:163-171

Bayerl KA, Hilgelke B (1994) The development of northern Sylt during the latest Holocene. Helgol wiss Meeresunters 48:145-162

Beukema JJ, Dekker R (2005) Decline of recruitment success in cockles and other bivalves in the Wadden Sea: possible role of climate change, predation on postlarvae and fisheries. Mar Ecol Prog Ser 287:149-167

Beukema JJ, Dekker R (2011) Increasing species richness of the macrozoobenthic fauna on tidal flats of the Wadden Sea by local range expansion and invasion of exotic species. Helgol Mar Res 65:155-164

Bouma TJ, Ortells V, Ysebaert T (2009) Comparing biodiversity effects among ecosystem engineers of contrasting strength: macrofauna diversity in Zostera noltii and Spartina anglica vegetations. Helgol Mar Res 63:3-18

Buschbaum C, Lackschewitz D, Reise K (2012) Nonnative macrobenthos in the Wadden Sea ecosystem. Ocean Coast Manag 68:89-101

Büttger H, Nehls G, Witte S (2011) High mortality of Pacific oysters in a cold winter in the North Frisian Wadden Sea. Helgol Mar Res 65:525-532

CPSL (2005) Coastal protection and sea level rise-solutions for sustainable coastal protection in the Wadden Sea region. Wadden Sea Ecosyst 21:1-47

Diederich S, Nehls G, van Beusekom JEE, Reise K (2005) Introduced Pacific oysters (Crassostrea gigas) in the northern Wadden Sea: invasion accelerated by warm summers? Helgol Mar Res 59:97-106

Dolch T (2008) High-resolution spatial analysis of morphodynamics and habitat changes in the Wadden Sea (SE North Sea). Diss. Univ. Kiel

Dolch T, Hass C (2008) Long-term changes of intertidal and subtidal sediment compositions in a tidal basin in the northern Wadden Sea (SE North Sea). Helgol Mar Res 62:3-11

Dolch T, Reise K (2010) Long-term displacement of intertidal seagrass and mussel beds by expanding large sandy bedforms in the northern Wadden Sea. J Sea Res 63:93-101

Dolch T, Buschbaum C, Reise K (2013) Persisting intertidal seagrass beds in the northern Wadden Sea since the 1930s. J Sea Res $82: 134-141$

Flach EC (1996) Distribution of Corophium at different scales. Senckenberg maritima 27:119-127

Gätje C, Reise K (eds) (1998) Ökosystem Wattenmeer - Austausch-, Transport- und Stoffumwandlungsprozesse. Springer, Berlin

Herlyn M, Millat G (2000) Decline of the intertidal blue mussel (Mytilus edulis) stock at the coast of Lower Saxony (Wadden Sea) and influence of mussel fishery on the development of young mussel beds. Hydrobiologia 426:203-210

Jensen KT (1992) Macrozoobenthos on an intertidal mudflat in the Danish Wadden Sea: comparison of surveys made in the 1930s, 1940s and 1980s. Helgol Meeresunters 46:363-376

Jensen J, Mügge H-E, Schönfeld W (1992) Analyse der Wasserstandsentwicklung und Tidedynamik in der Deutschen Bucht. Die Küste 53:211-275

Kemp AC, Horton BP, Donnelly JP, Mann ME, Vermeer M, Rahmstorf S (2011) Climate related sea-level variations over the past two millennia. PNAS 108:11017-11022

Kochmann J, Buschbaum C, Volkenborn N, Reise K (2008) Shift from native mussels to alien oysters: differential effects of ecosystem engineers. J Exp Mar Biol Ecol 364:1-10
Kolbe K, Kaminski E, Michaelis H, Obert B, Rahmel J (1995) Macroalgal mass development in the Wadden Sea-first experiences with a monitoring system. Helgol Meeresunters 49:519-528

Kolumbe E (1932) Ein Beitrag zur Kenntnis der Entwicklungsgeschichte des Königshafens bei List auf Sylt. Wiss Meeresunters Kiel 21:116-130

Kraan C, Dekinga A, Piersma T (2011) Now an empty mudflat: past and present benthic abundances in the western Dutch Wadden Sea. Helgol Mar Res 65:51-58

Kröncke I (2011) Changes in Dogger Bank macrofauna communities in the 20th century caused by fishing and climate. Estuar Coast Shelf Sci 94:234-245

Loebl M, van Beusekom JEE, Reise K (2006) Is spread of the neophyte Spartina anglica recently enhanced by increasing temperatures? Aquat Ecol 40:315-324

Lotze HK (2005) Radical changes in the Wadden Sea fauna and flora over the last 2,000 years. Helgol Mar Res 59:71-83

Lotze HK, Lenihan HS, Bourque BJ, Bradbury RH, Cooke RG, Kay MC, Kidwell SM, Kirby MX, Peterson CH, Jackson JBC (2006) Depletion, degradation, and recovery potential of estuaries and coastal seas. Science 312:1806-1809

Markert A, Wehrmann A, Kröncke I (2010) Recently established Crassostrea-reefs versus native Mytilus-beds: differences in ecosystem engineering affects the macrofaunal communities (Wadden Sea of Lower Saxony, southern German Bight). Biol Invasions 12:15-32

Müller F, Baessler C, Schubert H, Klotz S (2010) Long-term ecological research. Springer, Berlin. doi:10.1007/978-90-481$8782-9$

Nehls G, Diederich S, Thieltges DW, Strasser M (2006) Wadden Sea mussel beds invaded by oysters and slipper limpets: competition or climate control? Helgol Mar Res 60:135-143

Newig J (1980) Zur Entwicklung des Listlandes auf Sylt in den letzten drei Jahrhunderten - ein historisch-kartographischer Vergleich. Nordfries Jb 16:69-74

Pearson TH, Josefson AB, Rosenberg R (1985) Petersen's stations revisited. I. Is the Kattegatt becoming eutrophic? J Exp Mar Biol Ecol 92:157-206

Piersma T, Koolhaas A, Dekinga A, Beukema JJ, Dekker R, Essink K (2001) Long-term indirect effects of mechanical cockle-dredging on intertidal bivalve stocks in the Wadden Sea. J Appl Ecol 38:976-990

Priesmeier K (1970) Form und Genese der Dünen des Listlandes auf Sylt. Schr naturwiss Ver Schleswig-Holstein 40:11-51

Puls W, van Bernem KH, Eppel D, Kapitza H, Pleskachevsky A, Riethmüller R, Vaessen B (2012) Prediction of benthic community structure from environmental variables in a soft-sediment tidal basin (North Sea). Helgol Mar Res 66:345-362

Rasmussen E (1973) Systematics and ecology of the Isefjord marine fauna (Denmark). Ophelia 11:1-495

Reise K (1985) Tidal flat ecology. Ecological studies 54. Springer, Heidelberg, p 191

Reise K (1998) Pacific oysters invade mussel beds in the European Wadden Sea. Senckenberg maritima 28:167-175

Reise K (2005) Coast of change: habitat loss and transformations in the Wadden Sea. Helgol Mar Res 59:9-21

Reise K, Kohlus J (2008) Seagrass recovery in the northern Wadden Sea? Helgol Mar Res 62:77-84

Reise K, Siebert I (1994) Mass occurrence of green algae in the German Wadden Sea. Dtsch Hydrogr Z Suppl 1:171-180

Reise K, van Beusekom JEE (2008) Interactive effects of global and regional change on a coastal ecosystem. Helgol Mar Res 62:85-91 
Reise K, Herre E, Sturm M (1989) Historical changes in the benthos of the Wadden Sea around the island of Sylt in the North Sea. Helgol wiss Meeresunters 43:417-433

Reise K, Herre E, Sturm M (1994) Biomass and abundance of macrofauna in intertidal sediments of Königshafen in the northern Wadden Sea. Helgol wiss Meeresunters 48:201-215

Reise K, Simon M, Herre E (2001) Density-dependent recruitment after winter disturbance on tidal flats by the lugworm Arenicola marina. Helgol Mar Res 55:161-165

Reise K, Herre E, Sturm M (2008) Mudflat biota since the 1930s: change beyond return? Helgol Mar Res 62:13-22

Rosenberg R, Gray JS, Josefson AB, Pearson TH (1987) Petersen's benthic stations revisited. II. Is the Oslofjord and eastern Skagerrak enriched? J Exp Mar Biol Ecol 105:219-251

Schückel U, Kröncke I (2013) Temporal changes in intertidal macrofauna communities over eight decades: a result of eutrophication and climate change. Estuar Coast Shelf Sci 117:210-218

Tang M, Kristensen E (2010) Associations between macrobenthos and invasive cordgrass, Spartina anglica, in the Danish Wadden Sea. Helgol Mar Res 64:321-330

Valiela I (2005) Marine ecology processes. Springer, New York

van Beusekom JEE (2005) A historic perspective on Wadden Sea eutrophication. Helgol Mar Res 59:45-54

van Beusekom JEE, Bot PVM, Carstensen J, Göbel J, Lenhart H, Pätsch J, Petenati T, Raabe T, Reise K, Wetsteijn B (2009) Eutrophication. Thekatic Report 6. In: Marencic H, de Vlas J (eds) Quality Status Report 2009. Wadden Sea Ecosystem 25.
Common Wadden Sea Secretariat, Wilhelmshaven, Germany, $21 \mathrm{pp}$

van Goor MA, Zitman TJ, Wang ZB, Sztive MJF (2003) Impact of sea-level rise on the morphological equilibrium state of tidal inlets. Mar Geol 201:211-227

Vermeer M, Rahmstorf S (2009) Global sea level linked to global temperature. PNAS 106:21527-21532

Wahl T, Jensen J, Frank T, Haigh ID (2011) Improved estimates of mean sea level changes in the German Bight over the last 166 years. Ocean Dyn 61:701-715

Wang ZB, Hoekstra P, Burchard H, Ridderinkhof H, de Swart HE, Stive MJF (2012) Morphodynamics of the Wadden Sea and its barrier island system. Ocean Coast Manag 68:39-57

Weijerman M, Lindeboom H, Zuur AF (2005) Regime shifts in marine ecosystems of the North Sea and Wadden Sea. Mar Ecol Prog Ser 298:21-39

Weisse R, Plüß A (2006) Storm-related sea level variations along the North Sea coast as simulated by a high-resolution model 1958-2002. Ocean Dyn 56:16-25

Witte S, Buschbaum C, van Beusekom JEE, Reise K (2010) Does climatic warming explain why an introduced barnacle finally takes over after a lag of more than 50 years? Biol Invasions 12:3579-3589

Wohlenberg E (1937) Die Wattenmeer-Lebensgemeinschaften im Königshafen von Sylt. Helgol wiss Meeresunters 1:1-92 